\title{
Determination of Perceived Social Support and Burnout Levels of Mothers of Children with Intellectual Disability
}

\author{
(1) ilknur Kahrıman¹, (1) Sevinç Polat2, (1) Ayşe Gürol³ \\ ${ }^{1}$ Karadeniz Technical University Faculty of Health Science, Department of Pediatric Nursing, Trabzon, Turkey \\ 2Bozok University Faculty of Health Science, Department of Pediatric Nursing, Yozgat, Turkey \\ ${ }^{3}$ Atatürk University Health Services Vocational School, Department of Pediatric Nursing, Erzurum, Turkey
}

\begin{abstract}
Aim: The aim of this study is to determine the correlation between the perceived social support and burnout levels of the mothers of intellectually disabled (ID) children and the affecting factors.

Materials and Methods: This descriptive and cross-sectional study was conducted in the fourteen Special Training and Rehabilitation Centers in the city center of Trabzon between 15t June 2014 and 30th November 2014. The sample of the study consisted of 128 mothers who had 6-14 year old children with intellectual disability. The data of the study were collected using the Personal Information Form, Maslach Burnout Inventory, and Multidimensional Scale of Perceived Social Support.

Results: In this study, more than half of the mothers were determined to have difficulty in the care of their ID children. These mothers were found to have difficulty mostly because of financial problems and their children's aggressive behavior. It was determined that the relationships of one third of these mothers with their husbands and one fourth with their healthy children and relatives were negatively affected. The burnout levels of these mothers who had difficulty in the care of their ID children, were secondary school graduate, had an extended family, were unemployed, were on social security, and an ID boy, were found to be higher. In this study, while higher Multidimensional Scale of Perceived Social Support scores of the mothers were good it was unwanted stiuation their burnout levels were above the mean.

Conclusion: It is recommended to determine multiple factors causing burnout in the mothers of ID children, accordingly to support mothers using a multi-factorial team approach through different studies to be conducted concerning this matter, and for mothers to take short vacations and participate in activities they like.
\end{abstract}

Keywords: Burnout, child, intellectually disabled, mother, social support

\section{Introduction}

According to data from the World Health Organization, it is estimated that $10 \%$ of the total population in developed countries and $13 \%$ of the total population in developing counties consist of intellectually, physically, or emotionally disabled people. A disabled child or adult is found in one of every 7-8 families (1). The ratio of disabled children in Turkey is $12.3 \%(2)$.

When a child has a disability, all members of the family are affected to various degrees. The major caregiving responsibility usually falls to the mother (2-4). Mothers 
may experience intense stress due to these responsibilities, which can lead to burnout in them (4-7). Therefore, the causes of burnout experienced especially by mothers are important. Social support behaviors such as reducing the negative outcomes of the crisis experienced by families because they have a disabled child, making them feel valuable, and love will make adaptation of these families to this process easier and will help these families emotionally and physically $(2,8,9)$.

Social support patterns for families with a disabled child are divided into two categories, namely, formal and informal. While formal social support systems are perceived as being given by professionals, informal support systems are perceived as being given by family members, friends and being a member of social groups that are integrated into the family's daily life. Informal support is more efficient than formal support for protection against the negative effects of stress $(3,9)$.

One of the most important factors making it easier to successfully adapt to the presence of a disabled child is to provide support services that will both help to meet the needs of the child and the family and make it easier to reduce disability-related problems (10). Unfortunately, since fathers consider their children's disease or disability to be the fault of the woman in Turkey, they refuse to give their support to their wives and the woman's immediate surroundings do not provide the required support in the period when the woman needs it most with the concern that responsibility for care of a disabled child would be left to them, and these are quite overwhelming for the woman and result in burnout. Therefore, various support systems especially for mothers with intellectually disabled (ID) children to cope with high levels of stress occurring due to the difficulties they experience and comprehensive studies to raise awareness about this issue are needed.

The aim of this study is to determine the correlation between perceived social support and burnout levels of those mothers with ID children and to detect whether or not perceived social support and burnout levels of mothers differ depending on socio-demographic variables, difficulties experienced by mothers, and the state of their personal relationships.

\section{Materials and Methods}

This is a descriptive and cross-sectional study. The study was conducted in the fourteen Special Education and Rehabilitation Centers in the city center of Trabzon between $1^{\text {st }}$ June 2014 and 30 ${ }^{\text {th }}$ November 2014.
Ethics approval was received from Karadeniz Technical University Faculty of Medicine Scientific Research Ethics Committee (approval number: 24237859-179, date: 03.21.2014), a written permission from The Rehabilitation Centers in the city of Trabzon, and verbal consent from the participants were received. The principle of "Informed Consent" was fulfilled by informing mothers about purpose of the study, the principle of "Respect for Autonomy" was fulfilled by voluntary participation in the study and the principle of "Confidentiality and the Protection of Confidentiality" was fulfilled by saying that information to be obtained would be kept confidential.

\section{Population and Sample Group}

The population of the study consisted of the mothers of 220 ID children who were receiving regular physiotherapy and rehabilitation in special education and rehabilitation centers between the specified dates. The sample of the study consisted of 128 mothers who met the inclusion criteria and agreed to participate in the study. Children with ID, aged between 6-14 years, and informed consent of the legal primary caregiver of the child were the inclusion criteria. Families who refused to participate in the study, primary caregivers with cooperation problems and those who could not speak Turkish, and children having other disability problems (orthopedic, hyperactivity, or autism) were excluded from the study.

\section{Materials}

The data were collected using the Personal Information Form, Maslach Burnout Inventory (MBI) and Multidimensional Scale of Perceived Social Support (MSPSS).

Personal Information Form: The personal information form consists of 22 questions including the sociodemographic characteristics of the ID children and their mothers as well as their effects on their lives.

Maslach Burnout Inventory: The Maslach Burnout Inventory developed by Maslach et al. $(11,12)$ is by far the most popular instrument to assess burnout. The validated 22-item MBI was used to assess burnout because of its proven reliability, ease of completion, validity, and applicability to the general population. The $\mathrm{MBI}$ identifies the frequency (how often) various feelings occur over a 12 -month period, with a total of 22 questions grouped into the three dimensions, namely emotional exhaustion (EE) (EE; items 1, 2, 3, 6, 8, 13, 14, 16, and 20), depersonalization (DP) (DP; items 5, 10, 11, 15, and 22), and reduced personal accomplishment (PA) (PA; items 4, 7, 9, 12, 17, 18, 19, and 
21). The answer to each question rated the experiences on a 5-point Likert scale, ranging from "never" to "everyday" (13). High scores on emotional exhaustion and depersonalization and low scores on personal accomplishment are signs of burnout.

$\mathrm{MBI}$ had been translated into Turkish and used as a data collection instrument in the field of medicine before $(14,15)$. It was found to be reliable and valid. Ergin (15) found reliability coefficients to be 0.83 for $E E, 0.65$ for $D P$, and 0.72 for PA. Cronbach's alpha coefficient of the scale was determined to be 0.77 . Cronbach's alpha coefficient was 0.78 for the EE subscale, 0.66 for the DP subscale, and 0.67 for the PA subscale.

Multidimensional Scale of Perceived Social Support: The MSPSS total score was used in this study. The MSPSS is a self-rating tool of perceived social support consisting of 12 questions rated on a 7-point scale developed by Zimet et al. (16). Questions are divided into 3 groups: family, friends and significant other. The 7-point scale ranges from 1 "very strongly disagree" to 7 "very strongly agree". The total scale score was used in this study, which was obtained by finding the arithmetic mean of the sum of the scores on all the items. A high score indicates a high level of perceived social support. The items in the MSPSS have excellent internal consistency (Cronbach's alpha=0.840.92) and strong test-retest reliability ( $r=0.72-0.85)$ (17). Total and subscale scores are generated. Higher scores indicate better support. Internal consistency (0.90-0.95) and validity are excellent.

The lowest score to be obtained from the scale is 12 , the highest score is 84 . A validity and reliability study of the scale was conducted by Eker and Arkar (18) in Turkey. Cronbach's alpha coefficient was 0.89 for the scale, 0.85 for the family subscale, 0.88 for the friend subscale, and 0.92 for the significant other subscale (19). In this study, it was determined that Cronbach's alpha reliability was 0.88 for the scale, 0.81 for the significant other subscale, 0.82 for the family subscale, and 0.89 for the friend subscale.

\section{Data Collection}

The data were collected by researchers using the faceto-face interview method. It took on average 30-35 minutes to collect the data. The instruments were tested in a pilot study that included 10 mothers, and confirmed a high level of item acceptance and comprehension. The assessments were conducted by the children's own physiotherapists, who had at least 5 years of experience in treating disabled children.

\section{Statistical Analysis}

The SPSS 19.0 package software was used to analyze the data of the study. The data were assessed by using the Cronbach's alpha coefficient, percentage distribution, mean, standard deviation, Pearson's correlation analysis, independent samples t-test, one way analysis of variance (ANOVA) and the Tukey test as an advanced analysis for values determined to be significant in the analysis of variance. The confidence interval was 95\%; $p<0.05$ was considered to be statistically significant.

\section{Results}

\section{The Socio-demographic Characteristics of Participants}

It was determined that $40.6 \%$ of the mothers were 40 years old or older, $65.6 \%$ were primary school graduates, $7 \%$ were employed, $85.9 \%$ had a nuclear family, $18.8 \%$ had 4 or more children, and $32.8 \%$ had kinship with their spouses. The average age of the disabled children included in the study was $11.30 \pm 3.88$ years and $58.6 \%$ were male (Table I).

Comparison of the Mothers' Characteristics and the Multidimensional Scale of Perceived Social Support

In the study, it was found that the mothers' mean scores were $58.22 \pm 19.46$ from MSPSS, 19.92 \pm 7.97 from the significant other subscale, $19.97 \pm 7.80$ from the family subscale, and $18.32 \pm 8.58$ from the friend subscale.

MSPSS mean scores of mothers aged between 20-30 years were $62.04 \pm 14.45$. There was a statistically significant difference between mother's age and the family subscale's

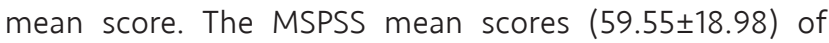
married women were higher than single women and the difference between marital status and MSPSS/subcales (significant other and friend subscales) was statistically significant. In the study, the subscales' mean scores of those mothers who had an extended family type were higher than the others and the difference between family type and the significant other subscale was statistically significant. MSPSS and its subscales' mean scores of those women who had no kinship with their spouses were higher and the difference between them was statistically significant (Table I).

In the study, the percentage of mothers who have difficulty in the care of their ID children was $61.7 \%$. These mothers experienced financial problems, moral depression, and difficulty due to the extremely angry and aggressive behaviors of their disabled child. In the study, the percentage of mothers whose relationships with their husband was 
negatively affected was $22.7 \%$, with their healthy children, the percentage was $19.5 \%$, and with their relatives, it was $17.2 \%$ (Table II).

It was found that there was a statistically significant difference between mothers who have difficulty in their child's care, have financial difficulty and mean scores of the friend subscale. There was a statistically significant difference between mothers affected relationship with relatives, receiving support in care and mean scores of the family subscale $(p<0.05$, Table II).

\section{Comparison of the Mothers' Characteristics and the Maslach Burnout Inventory}

The total mean scores of $\mathrm{MBI}$ were $29.11 \pm 12.14$. It was found that the EE subscale's mean score was 14.83 \pm 7.78 , the DP subscale's mean score was $4.94 \pm 4.03$, and the PA subscale's mean score was $9.33 \pm 5.60$.

In this study, there was found to be a statistically significant negative correlation between the family's income level and the mean scores of the DP subscale. It was determined that there was no significant correlation between the age of the ID children and the mean scores of the MBI (Table III).

In this study, the MBI's mean scores of those mothers aged between 20 -30 years and over 40 years were $29.23 \pm 10.82$ and $29.82 \pm 12.26$, respectively. Those mothers who had graduated from a university had lower scores for the $\mathrm{MBI}$ and its subscales. It was determined that the difference between mothers' socio-demographic characteristics and the mean scores of the $\mathrm{MBI}$ was not statistically significant (Table III).

The MBI's mean scores $(30.53 \pm 12.27)$ of those mothers who had difficulty in the care of their child were higher. In this study, the difference between those mothers who had difficulty in the care of their children and the mean scores of the EE and DP subscales were statistically significant $(\mathrm{p}<0.05$, Table IV).

It was determined that those mothers who stated the status of their relationship as "no knowledge about their spouse", were $13.14 \pm 6.51$ of the PA subscale's mean scores and the difference between them was statistically significant. The EE and DP subscales' mean scores of those mothers with financial difficulties were 20.27 \pm 8.62 and $7.63 \pm 4.24$, respectively. Those mothers supported by their surrounding (neighbors, relatives), it was $19.80 \pm 13.47$ for the mean score of the PA subscale and the difference between them was statistically significant.
Correlation Between Multidimensional Scale of Perceived Social Support and Maslach Burnout Inventory

In this study, there was a negative significant correlation $(r=-0.216, p=0.014)$ between the mean scores of the family subscale and the mean scores from the PA subscale. It was determined that there was also a negative significant correlation among the mean scores of the friend subscale and the mean scores of the $\mathrm{MBI}$ and its EE and DP subscales (respectively, EE: $r=-0.178, p=0.044$; DP: $r=-0.180, p=0.042$; MBI: $r=-0.192 ; p=0.030)$, (Table V).

\section{Discussion}

\section{Comparison of Some of the Mothers' Characteristics and the Multidimensional Scale of Perceived Social Support}

It was found that there was a positive significant correlation among family's income level and the mean scores of the MSPSS, significant other and friend subscales. Gölamış (20) found that the mothers' perceived social support levels differed according to level of income. Erhan (21) stated that mothers received lower social support as their income level decreased. The results of this study were found to be similar to those results of the previous studies.

Those mothers aged between 20-30 years had higher mean scores on the family subscale. There was a statistically significant difference between the mother's age and the mean scores of the family subscale. This result can be explained by the fact that young mothers are supported by their families more until they get used to this situation and learn how to cope with the problem.

It was seen that married mothers had higher means scores on the MSPSS, significant other and friend subscales. It can be asserted that mothers receive more social support because marriage is an entity accepted by the family and social surrounding due to the structure of Turkish society. It was thought that the low number of single mothers compared to married ones was also effective in this result. In contrast to the results of this study; Hartley and Schultz (22) reported that mothers displayed more symptoms of stress and depression compared to fathers amongst the married couples and accordingly mothers had more unmet social support needs.

In this study, those mothers who had an extended family type had higher mean scores on the MSPSS, and its subscales. There was a statistically significant difference between family type and mean scores on the significant other subscale. This case can be explained by the fact that the mother received more support for household chores, 
Kahrıman et al.

Perceived Social Support and Burnout Levels of Mothers

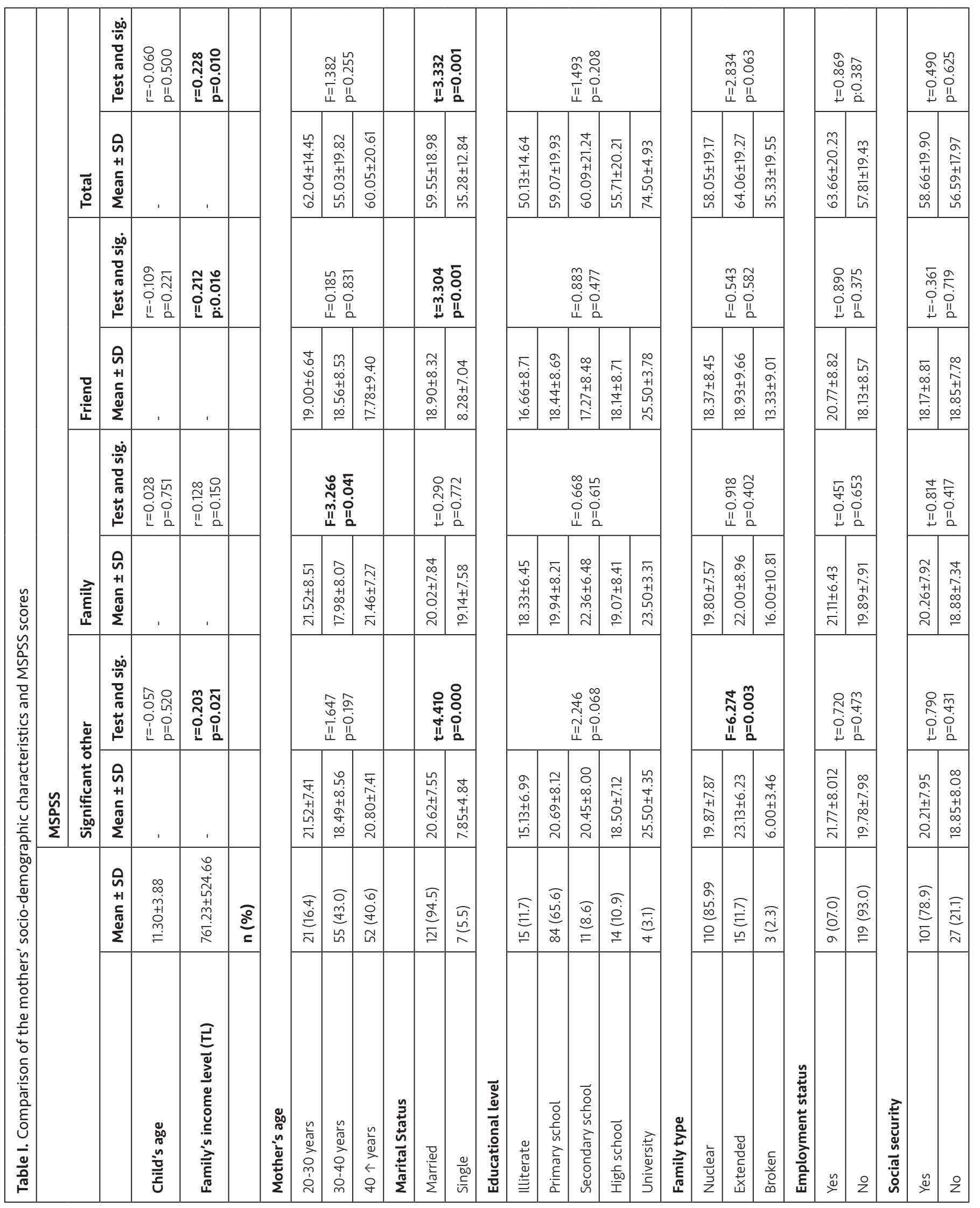




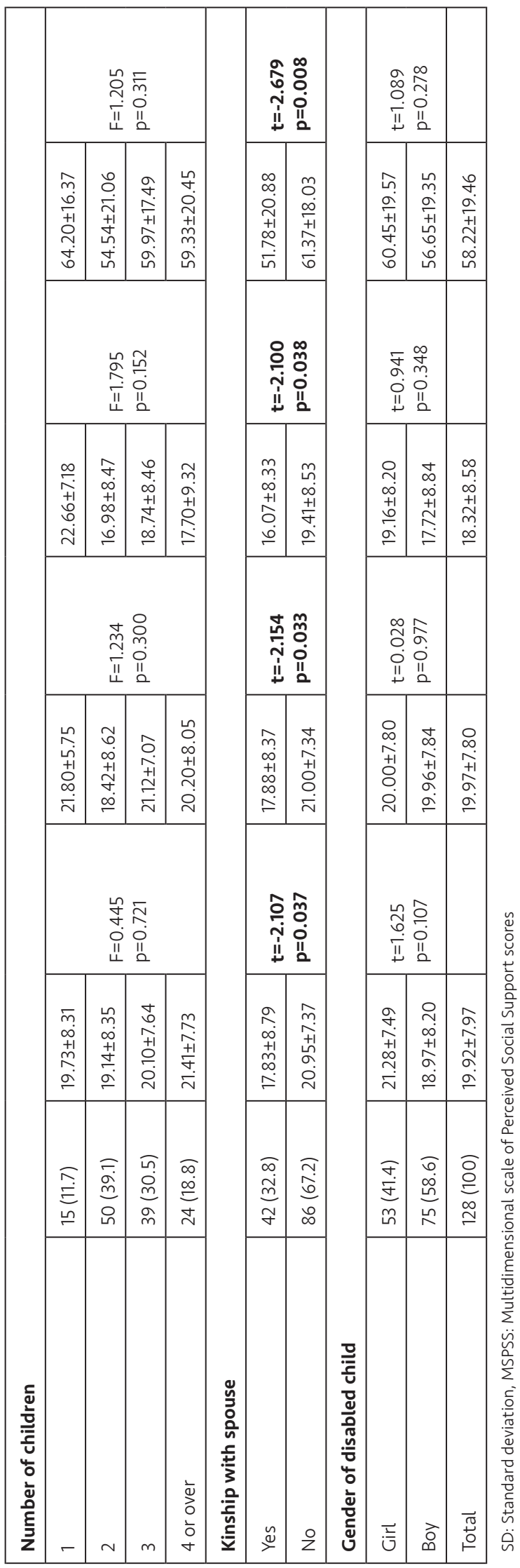

personal care or social relationships even though she is the primary person responsible for the child's care in extended families. In the study of Kırbaş and Özkan (23), mothers living in an extended family had higher mean scores of perceived social support from the family than for those mothers who lived in a nuclear family. Bahar et al. (24), reported that social the support needs of mothers living in an extended family were lower. The results of this study were found to be similar to the literature $(24,25)$.

In this study, mothers who had kinship with their spouse had lower mean scores on the MSPSS and its subscales. The difference between them was statistically significant (Table I). This result can be explained by the fact that the families of the woman and man do not provide the required support because of the concern that they will have to take the responsibility for the disabled child's care in the future.

It was reported that those mothers who had difficulty in the child's care had lower mean scores on the MSPSS and its subscales (Table II). These mothers were having difficulty especially because of financial problems, the child's aggressive behavior and their unmet personal needs according to this study. It has been reported in related studies that mothers of children with a chronic disease or any kind of disability need more social support compared to fathers $(22,26)$. This situation might be a reflection of the mothers' undertaking of the child care role to a greater extent. Kahriman and Bayat (27) determined that all of the parents had difficulty in the child's care and $26.7 \%$ received support for the care of their disabled child.

In the present study, it was determined that the relationships of one third of the mothers with their husbands and nearly one fourth of their relationships with their healthy children and relatives were affected $(p>0.05$, Table II). Similar to the results of the present study, the study of Aylaz et al. (7) revealed that having an autistic child negatively affected the relationships of family members with each other, couples did not allocate time for each other, their sharing reduced, and they blamed each other for a long time. Also, in their study, Kahriman and Bayat (27) found that mothers' relationships with their husband, other children, relatives and neighbors were negatively affected because they had a disabled child and the social support mean scores of these mothers whose relationships were negatively affected were lower.

Mothers who stated that their relationships with their relatives were not influenced because of having a disabled child, were found to have higher mean scores on the family 
Kahrıman et al.

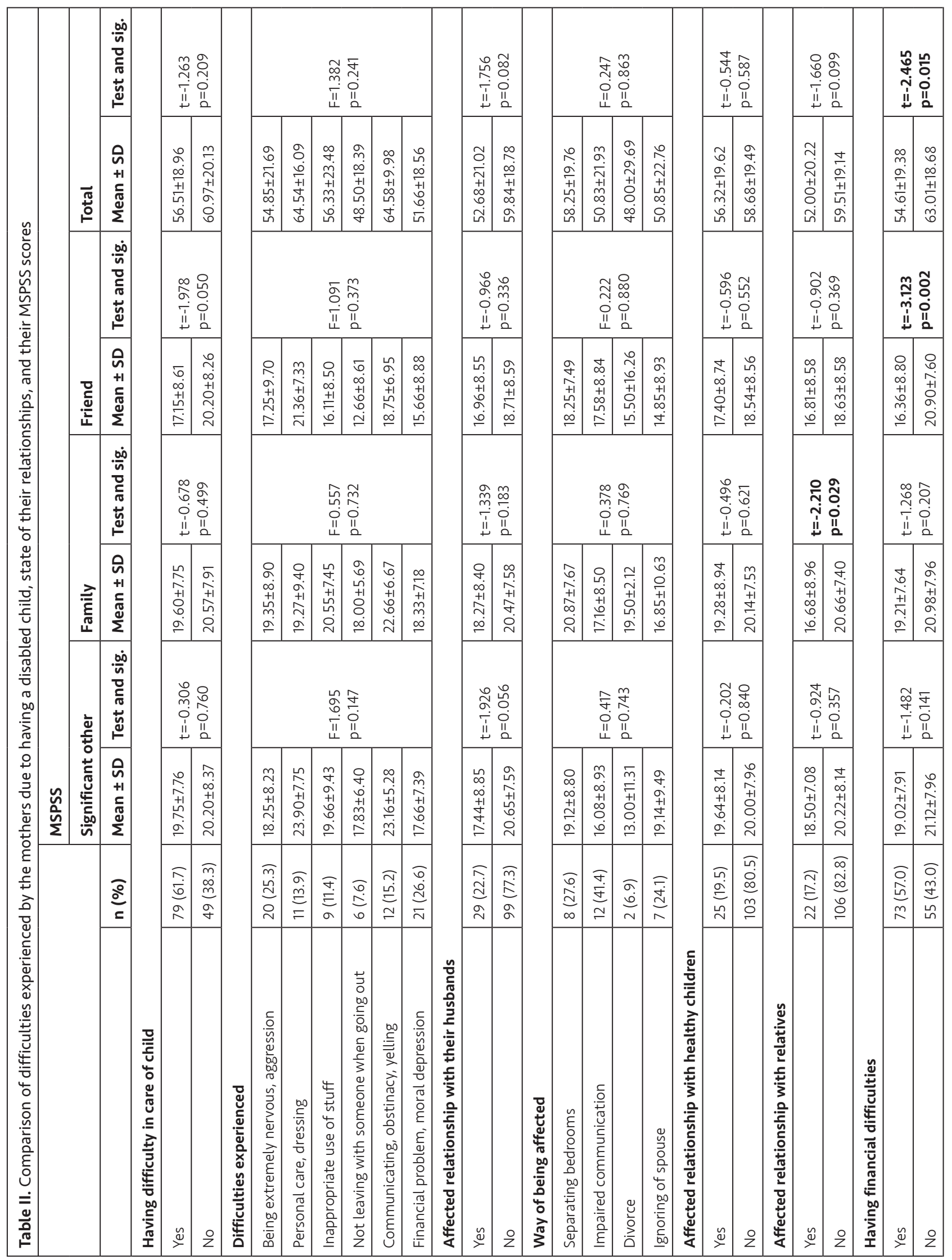




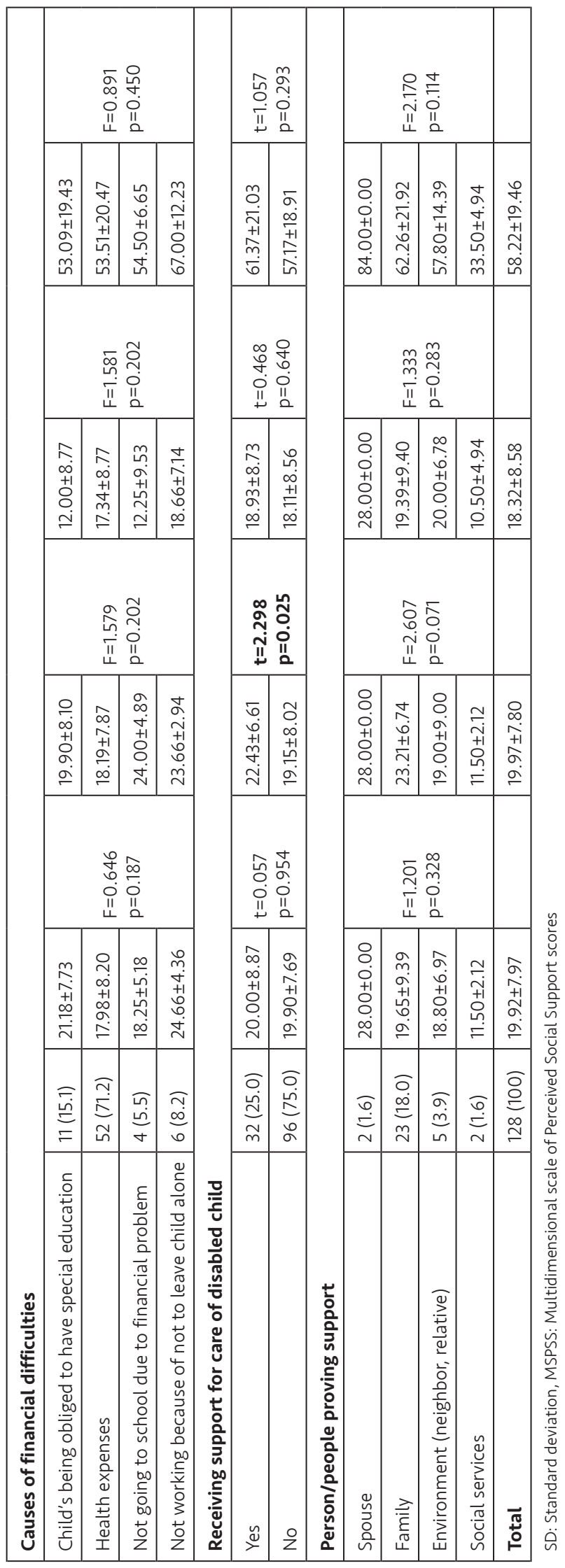

subscale of the MSPSS (Table II). This result indicates that perceived social support from the family had an important role in the relationships of these mothers. It is also emphasized in the literature that the mothers' religious beliefs could make a positive contribution to the marital relationship and behaviors among family members (28).

In this study, it was determined that those mothers who did not have financial problems had higher mean scores on the MSPSS and its friend subscale. There was a statistically significant difference between them (Table II). Studies revealed that families of children with special needs have a narrower social support network which is limited with family members and close friends (29). In this situation, it can be asserted that support by close family members and close friends, who are the only and the closest support group for parents, is important in this process. Karpat and Girli (30) determined that parents considered their families to be the social support source in the first rank, their friends in the second rank, and people within the significant other category in the third rank. "Significant other" was defined as a person other than family or friends (for example; girlfriend, boyfriend, fiancée, relative, neighbor, doctor). When considering the whole, the sample group utilized from special education, trainers also can be included in the "significant other" category specific to this study. As in this study, professionals to whom trainers and mothers have a relationship with, can be asserted to be functional as a social support source.

It was determined that the mothers had good level mean scores on the MSPSS and they had moderate level mean scores of its subscales in this study. Karadağ (29) reported that mothers with disabled children did not have adequate social support. It is important that parents with a disabled child receive social support from their surrounding, especially from relatives. This is because the behavior of the child and family and their development in terms of various aspects are positively influenced with good social support. At the same time, parents who share their responsibilities with other people are supported by the surrounding people and so think they are not alone allowing them to cope with the problems more easily (29).

\section{Comparison of Some of the Mothers' Characteristics and the Maslach Burnout Inventory}

In this study, more than half of the mothers were determined to have difficulty in the care of their ID child. The difference between those mothers who had financial problems due to the care of their children and the mean scores of the EE and DP subscales was statistically 
Kahrıman et al.

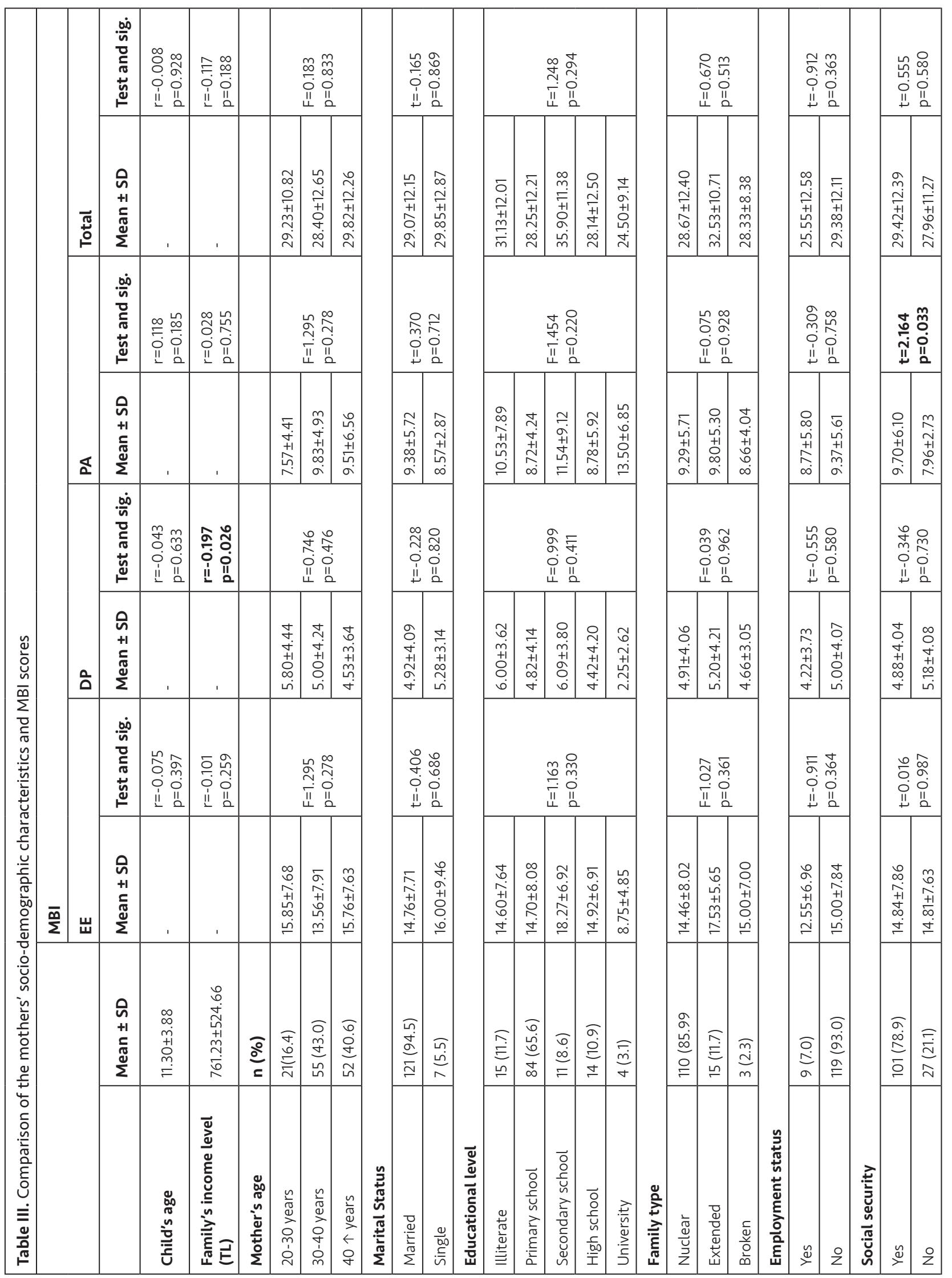




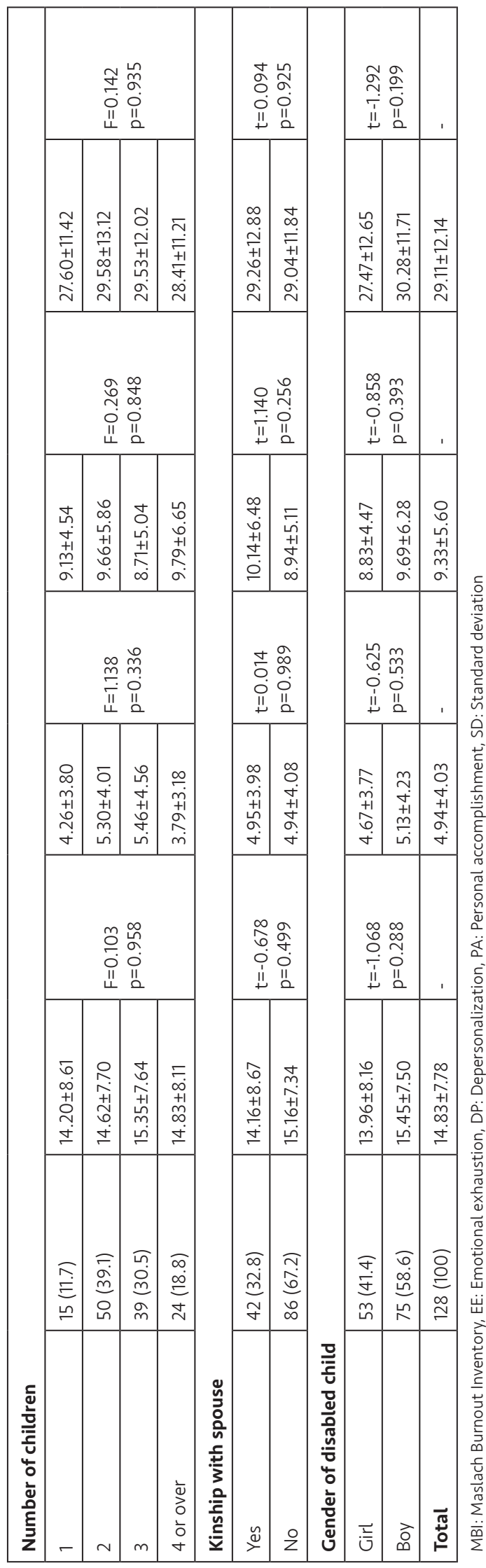

significant (Table IV). These results are important in terms of revealing the importance of being supported regarding physical and financial difficulties experienced by these mothers.

Those mothers who were ignored or divorced by their husbands had higher scores on the PA subscale (Table IV). This result can be asserted as an indicator for women's coping with difficulties in the absence of their husbands and the struggle to be successful. Having a disabled child creates new problems since it comes with responsibilities such as the care of the child, health, education, and social relations. Thus, couples experience burnout in their relationship. Even though the couples' burnout does not always lead to divorce, it reduces the quality of the relationship. In this case, they might perceive their whole relationship to be complicated and compelling (31). Improving marital satisfaction, co-parenting and parenting practices would reduce parental burnout. Hence, in cases where the child also suffers from a chronic disease, it may therefore be of particular importance for healthcare practitioners to emphasise the importance of shared parental responsibility to prevent stress and burnout in mothers (32).

In this study, it was determined that the MBI's mean score of those mothers whose relationships with their relatives were negatively affected were higher and the difference between them was statistically significant. These mothers with children exhibit high levels of stress, a high rate of psychological problems, and burnout. It is of great importance that mothers are supported in coping with these issues and maintaining their health in this context. It is stated that social support reduces stress, contributes to developing positive coping skills and diminishes burnout (33).

It was determined that mothers who had financial problems due to the special education of their child received higher mean scores on the EE and DP subscales and the difference between them were statistically significant. In the literature, financial difficulties increase stress and influenced mental health. It is pointed out that a family's financial status has an effect on the parents' coping with their child's limitations (33). Studies have demonstrated that carers for ID children experience additional psychological distress and depression compared to the parents of normal children. Some studies have also reported negative outcomes among the carers such as physical problems, social, as well as financial issues for the child's family. This often leads to marital breakdowns and divorce (34). 
Kahrıman et al.

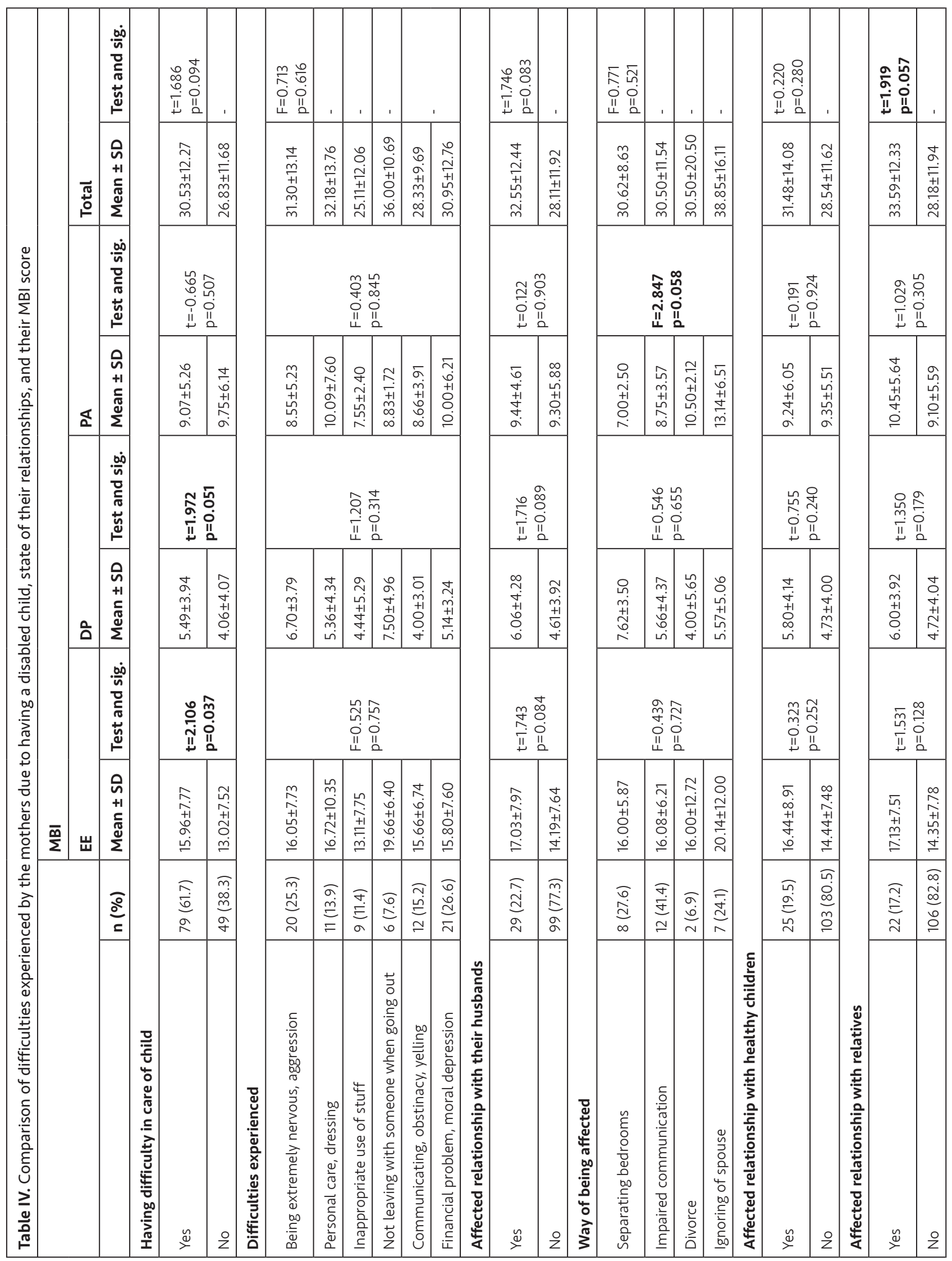




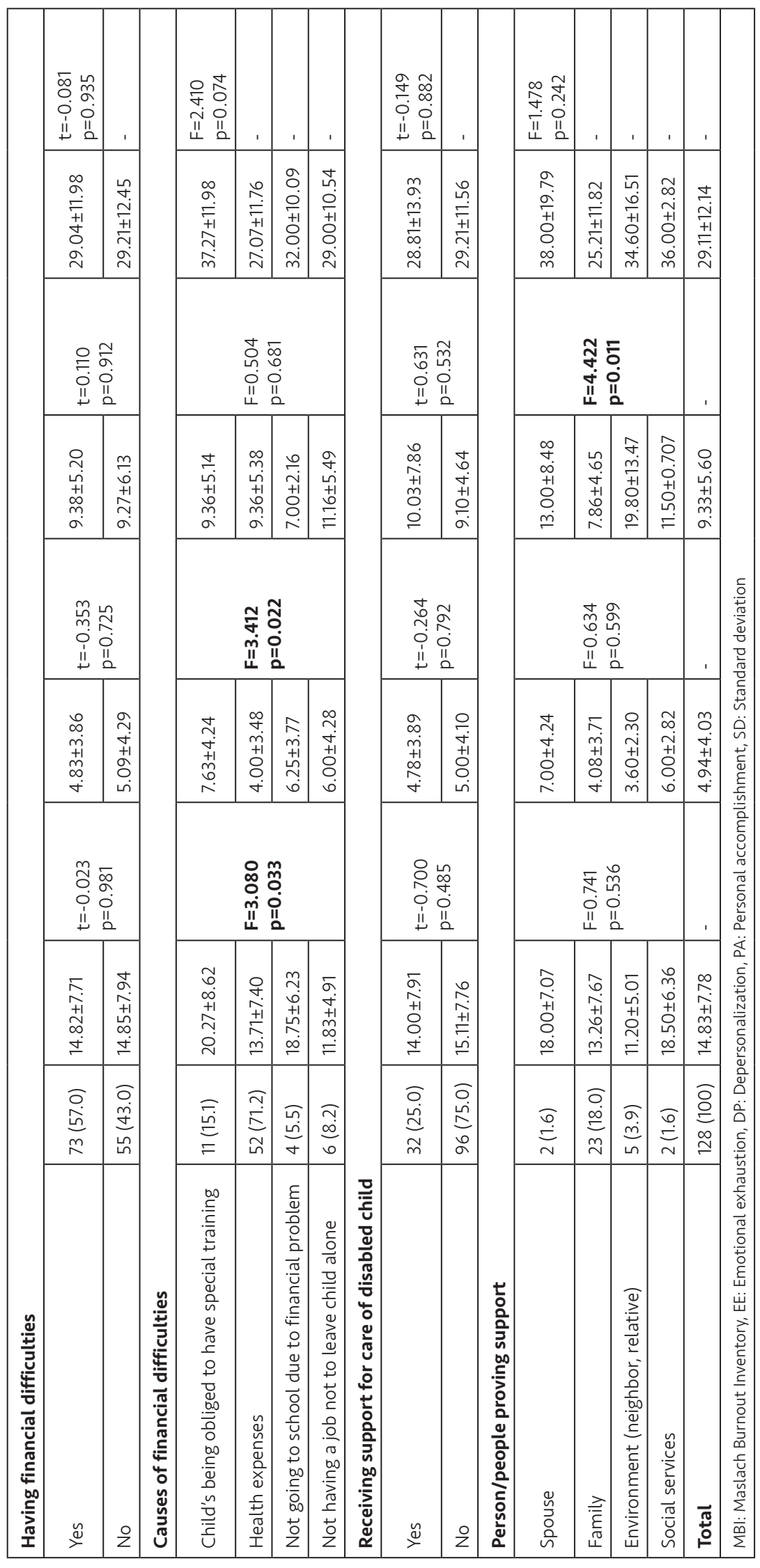

\section{Correlation Between Multidimensional} Scale of Perceived Social Support and Maslach Burnout Inventory scales

In this study, it was determined that there was a significant negative correlation between the mean scores received from the $\mathrm{MBI}$ and its EE and DP subscales and those received from the friend subscale. $A$ negatively significant correlation was also found between the PA subscale and the family subscale (Table $\mathrm{V}$ ). When examining correlations between the subscales of the scales used in the study, it was observed that the correlations of the subscales of the scales with each other were significant and high, and also the direction of correlations were in the expected direction according to the contents of the subscales. As the social support mothers received from their friends increased, their mean scores of $E E$, DP, and MBI decreased; as the social support recieved from the family increased, their mean scores of the PA subscale decreased. The results of the study were found to be similar to the information stated in the literature and revealed that social support decreases burnout levels.

It was determined in this study that those mothers who were having difficulty in the care of their child experienced burnout more. Generally, it supports the results indicating that having inadequate social support could cause burnout and emotional exhaustion is associated with friendship sources. Social support has a more important place in the lives of families who have a disabled child when compared to other families. It was also shown that the failure to adequately benefit from the perceived social support from friends was associated with emotional exhaustion, depersonalization and burnout (4). Duygun (35) stated that one of the factors related to emotional exhaustion of mothers who have an ID child was the search for social support.

Perceived social support (spouse, neighbor, family, relative, people 
Table V. Evaluation of correlation between Multidimensional Scale of Perceived Social Support scores and Maslach Burnout Inventory scales

\begin{tabular}{|c|c|c|c|c|}
\hline & $\begin{array}{l}\text { Emotional } \\
\text { exhaustion }\end{array}$ & Depersonalization & Personal accomplishment & Total MBI \\
\hline Significant other & $\begin{array}{l}r=-0.039 \\
p=0.660\end{array}$ & $\begin{array}{l}r=-0.102 \\
p=0.253\end{array}$ & $\begin{array}{l}r=0.005 \\
p=0.957\end{array}$ & $\begin{array}{l}r=-0.057 \\
p=0.524\end{array}$ \\
\hline Family & $\begin{array}{l}r=0.010 \\
p=0.910\end{array}$ & $\begin{array}{l}r=-0.074 \\
p=0.403\end{array}$ & $\begin{array}{l}r=-0.216 \\
p=0.014\end{array}$ & $\begin{array}{l}r=-0.118 \\
p=0.185\end{array}$ \\
\hline Friend & $\begin{array}{l}r=-0.178 \\
p=0.044\end{array}$ & $\begin{array}{l}r=-0.180 \\
p=0.042\end{array}$ & $\begin{array}{l}r=-0.040 \\
p=0.657\end{array}$ & $\begin{array}{l}r=-0.192 \\
p=0.030\end{array}$ \\
\hline Total MSPSS & $\begin{array}{l}r=-0.091 \\
p=0.308\end{array}$ & $\begin{array}{l}r=-0.151 \\
p=0.089\end{array}$ & $\begin{array}{l}r=-0.102 \\
p=0.252\end{array}$ & $\begin{array}{l}r=-0.155 \\
p=0.080\end{array}$ \\
\hline
\end{tabular}

MBI: Maslach Burnout Inventory, MSPSS: Multidimensional Scale of Perceived Social Support

subsidizing, friends) have a protective effect on the psychological health and well-being and a positive effect on preventing burnout. One of the most important factors in preventing burnout is to take short breaks from the work performed by mothers in order to refresh their intellectual and emotional resources (36).

\section{Conclusion}

In this study, more than half of mothers were determined to have difficulty in the care of their ID child. Mothers were found to have difficulty mostly due to financial problems and the aggressive behavior of the child. The relationships of one third of the mothers with their husbands and one fourth with their healthy children and relatives were affected negatively. A positive significant correlation was determined between the family's income level and the MSPSS, significant other and friend subscales of the scale. The burnout levels of those mothers who had difficulty in the care of their ID children, had only graduated from secondary school, had an extended family, were unemployed, used social security and had an ID boy were found to be higher. In this study, while higher MSPSS scores of the mothers were good it was unwanted stiuation their burnout levels were above the mean.

In accordance with the results obtained from the research; it is recommended to determine the multiple factors causing burnout in mothers of ID children through different studies to be conducted on this subject, to support mothers by using a multi-factorial team approach towards this goal, to positively change the perception of society regarding ID children, to increase the number of official institutions to be utilized by these children in terms of special education and social aspects and the number of employees, to provide counseling services to support the mother and child, to extend the context of legal regulations with government support, and for mothers to take short vacations and participate in activities they enjoy.

\section{Ethics}

Ethics Committee Approval: Ethics approval was received from Karadeniz Technical University Faculty of Medicine Scientific Research Ethics Committee (approval number: 24237859-179, date: 03.21.2014).

Informed Consent: Written permission from The Rehabilitation Centers in the city of Trabzon, and verbal consent from the participants were received.

Peer-review: Externally and internally peer-reviewed.

\section{Authorship Contributions}

Surgical and Medical Practices: I.K., Concept: I.K., S.P., Design: S.P., Data Collection or Processing: I.K., S.P., Analysis or Interpretation: A.G., Literature Search: I.K., A.G., Writing: I.K., A.G.

Conflict of Interest: The authors have no conflicts of interest relevant to this article to disclose.

Financial Disclosure: The authors have no financial relationships relevant to this article to disclose.

\section{References}

1. Lafçı D, Öztunç G, Alparslan ZN. Zihinsel engelli çocukların (mental retardasyonlu çocukların) anne ve babalarının yaşadığı güçlüklerin belirlenmesi. Gümüşhane Üniversitesi Sağlık Bilimleri Dergisi 2014;3:723-35.

2. Şimşek IE, Erel S, Tarsuslu Şimşek T, et al. Factors related to the Impact of chronically disabled children on their families. Pediatric Neurology 2014;50:255-61.

3. Kaner S. Aile destek ölçeği: Faktör yapısı, güvenirlik ve geçerlik çalışmaları. Ankara Üniversitesi Eğitim Bilimleri Fakültesi Özel Eğitim Dergisi 2003;4:57-72. 
4. Duygun T, Sezgin N. Zihinsel engelli ve sağlıklı çocuk annelerinde stres belirtileri, stresle başaçıkma tarzları ve algılanan sosyal desteğin tükenmişlik düzeyine olan etkisi. Türk Psikoloji Dergisi 2003;18:37-52.

5. Çengelci B. Otizm ve down sendrom'lu çocuğa sahip annelerin kaygı, umutsuzluk ve tükenmişlik duygularının karşılaştırılması. Ege Eğitim Dergisi 2009;10:1-22.

6. Doğru SSY, Arslan E. Engelli çocuğu olan annelerin sürekli kaygı düzeyi ile durumluk kaygı düzeylerinin karşılaştırılması. Selçuk Üniversitesi Sosyal Bilimler Enstitüsü Dergisi 2008;19:543-55.

7. Aylaz R, Yılmaz U, Polat S. Effect of difficulties experienced by parents of autistic children on their sexual life: a qualitative study. Journal Sexuality and Disability 2012;30:395-406.

8. Özşenol F, Işıkhan V, Ünay B, Aydın Hi, Akın R, Gökçay E. The evaluation of family functions of families with handicapped children. Gülhane Medical Journal 2003;45:156-64.

9. Meral BF, Cavkaytar A. A study on social support perception of parents who have children with autism. International Journal on New Trends in Education and Their Implications 2012;3:124-35.

10. Hung LC, Liu CC, Hung HC, Kuo HW. Effects of a nursing Intervention program on disabled patients and their caregivers. Archives of Gerontology and Geriatrics 2003;36:259-72.

11. Maslach C, Jackson SE. Maslach Burnout Inventory; manual research edition. Palo Alto, CA: Consulting Psychologists Press, 1986.

12. Maslach C, Jackson SE, Leiter MP. Maslach Burnout Inventory, 3rd ed. Palo Alto, CA: Consulting Psychologists Press, 1996.

13. Coker OA, Omoluabi PF. Validation of maslach burnout inventory. IFE psycholagia 2009;17:1-32.

14. Çam O. Investigating the reliability and validity of $\mathrm{MBI}$ : A report. VII. Ulusal Psikoloji Kongresi: Ankara. 1992.

15. Ergin C. Doktor Ve Hemşirelerde Tükenmişlik Ve Maslach Tükenmişlik Envanterinin Uyarlanması. 7. Psikoloji Kongre Kitabı. Ankara: Psikologlar Derneği Yayınları, 1992.

16. Zimet G, Dahlem N, Zimet S, Farley G. The multidimensional scale of perceived social support. J Pers Assess 1988;52:30-41.

17. Zimet GD, Powell SS, Farley GK, Werkman S, Berkoff KA. Psychometric characteristics of the Multidimensional Scale of Perceived Social Support. I Pers Assess 1990;55:610-7.

18. Eker D, Arkar H. Çok boyutlu algılanan sosyal destek ölçeği'nin faktör yapısı, geçerlik ve güvenirliği. Türk Psikoloji Dergisi 1995;34:45-55

19. Eker D, Arkar H, Yaldız H. Çok boyutlu algılanan sosyal destek ölçeği'nin gözden geçirilmiş formunun faktör yapısı, geçerlik ve güvenirliği. Türk Psikiyatri Dergisi 2001;12:17-25.

20. Gölamış EG. Zihinsel engelli çocuğu olan annelerin umutsuzluk, karamsarlık, sosyal destek algılarının ve gelecek planlarının incelenmesi. Ankara Üniversitesi Eğitim Bilimleri Enstitüsü, Yayınlanmamış Yüksek Lisans Tezi. Ankara, 2005.

21. Erhan G. Zihinsel engelli çocuğu olan annelerin umutsuzluk, kararsızlık, sosyal destek algıları ve gelecek planlarının incelenmesi. Ankara Üniversitesi Eğitim Bilimleri Enstitüsü, Ankara, 2005.
22. Hartley SL, Schultz HM. Support needs of fathers and mothers of children and adolescents with autism spectrum disorder. I Autism Dev Disord 2015;45:1636-48.

23. Kırbaş ZÖ, Özkan H. Down sendromlu çocukların annelerinin aile işlevlerini algılama ve sosyal destek düzeylerinin değerlendirilmesi. İzmir Dr. Behçet Uz Çocuk Hastalıkları Dergisi 2013;3:171-80.

24. Bahar A, Bahar G, Savaş HA, Parlar S. Engelli çocukların annelerinin depresyon ve anksiyete düzeyleri ile stresle başa çıkma tarzlarının belirlenmesi. Fırat Sağlık Hizmetleri Dergisi 2009; 4:97-112.

25. Sarı HY. Down sendromlu çocuğu olan ailelere yönelik bir durum çalışması. Sağlık Bilimleri Enstitüsü, Çocuk Sağlığı ve Hastalıkları Hemşireliği Anabilim Dalı. Yüksek Lisans tezi, İzmir: Dokuz Eylül Üniversitesi, 2001.

26. Bromely J, Hare DJ, Davidso K, Emerson E. Mothers supporting children with autistic spectrum disorders: Social support, mental health status, and satisfaction with services. Autism 2004;8:409-23.

27. Kahriman G, Bayat M. Özürlü çocuğa sahip ebeveynlerin yaşadıkları güçlükler ve algıladıkları sosyal destek düzeyleri. Öz-Veri Dergisi 2008;5:1175-94.

28. Cangür Ş, Civan G, Çoban S, et al. Düzce ilinde bedensel ve/ veya zihinsel engelli bireylere sahip ailelerin toplumsal yaşama katıımlarının karşılaştırmalı olarak değerlendirilmesi. Düzce Üniversitesi Sağlık Bilimleri Enstitüsü Dergisi 2013;3:1-9.

29. Karadağ G. Engelli çocuğa sahip annelerin yaşadıkları güçlükler ile aileden algıladıkları sosyal destek ve umutsuzluk düzeyleri. TAF Prev Med Bull 2009;8:315-22.

30. Karpat D, Girli A. Yaygın gelişimsel bozukluk tanılı çocukların anne-babalarının yas tepkilerinin, evlilik uyumlarının ve sosyal destek algılarının incelenmesi. Ankara Üniversitesi Eğitim Bilimleri Fakültesi Özel Eğitim Dergisi 2012;13:69-85.

31. Aydogan D, Kizildag S. Examination of relational resilience with couple burnout and spousal support in families with a disabled child. The Family Journal 2017;25:407-13.

32. Mikolajczak M, Raes ME, Avalosse H, Roskam I. Exhausted parents: Socio-demographic, child-related, parent-related, parenting and family-functioning correlates of parental burnout. Journal of Child and Family Studies 2018;27:602-14.

33. Cenk SC, Muslu CK, Sarlak D. The effectiveness of structured supported education programs for families with intellectually disabled children: The example of Turkey. Archives of psychiatric nursing 2016;30:704-9.

34. Masulani-Mwale C, Mathanga D, Kauye F, Gladstone M. Psychosocial Interventions for Parents of Children with Intellectual Disabilities-A narrative review and implications for low income settings. Mental Health \& Prevention 2018;11:24-32.

35. Duygun T. Zihinsel engelli ve sağııkı çocuk annelerinde stres belirtileri stresle başa çıkma tarzları ve algılanan sosyal desteğin tükenmişlik düzeyine olan etkisi. Yüksek Lisans Tezi, Ankara Üniversitesi Sosyal Bilimler Enstitüsü, Ankara, 2001.

36. Akgün E. Annelerde stres ve tükenmişlik. International Journal of Human Sciences 2014;11:238-50. 